\title{
More about Social Responsibility
}

Societues established to promote an awareness among scientists and the general public of the social consequences of science and technology tend to have a short half-life. But Pugwash, with its membership drawn from the international scientific élite and its government subsidies in one form or another, has not only survived but can claim to have influenced international policy. In Britain at least, national societies have either changed their character or withered as members lose enthusiasm when they realize the difficulties of producing tangible results. Lack of any sense of achievement seems to be the chief reason for this seemingly inevitable decline in societies which start with so much enthusiasm. The latest British society in the field, the British Society for Social Responsibility in Science, will launch itself on April 19 by holding a one day symposium at the Royal Society. It hopes to succeed where others have failed by tackling local as well as intornational issues and by harnessing the current student unrest over the state of society.

The BSSRS, which has already attracted a great deal of publicity, apparently stems from the discussions of seven or eight people after the symposium on chemical and biological warfare held last summer by the Bernal Peace Library. Early this year, this ad hoc committee sent to 180 eminent scientists a letter outlining the aims of the society and inviting membership, and signed by Professors C. F. Powell, M. H. F. Wilkins and M. Pollock and Drs R. L. Smith, D. H. Butt and S. Rose. The response so far should ensure that by April 19 the society will have the 100 founder members it seeks. 'The letter, in suitably broad (crities would say vague) terms, announced that the society has three chief aims: to stimulate among scientists an awareness of the social significance of their work and their individual and collective responsibilities; to draw attention to social, political and economic pressures affecting the development of science; and to draw public attention to these issues and create an informed public opinion. The letter also outlined proposed activities under three broad heads: first, to identify, do research on and publicize developments likely to have a major influence on life and the environment; second, to urge changes in undesirable aspects of scientific policy; and third, to urge reform in all levels of science education and to make clear the social role of science and the responsibilities of scientists.

Such a grand manifesto invites scepticism, of coursc. What does it all boil down to in practice? Where is the money to come from? How will the society avoid duplicating work done by Pugwash and other organizations? So far the ad hoc committee has organized three private meetings in London, attended by about fifty people and chiefly advertised by word of mouth around London University, to discuss practical moves. At the third of these meetings last week, an outline of a plan of campaign was discussed. The society plans to organize working groups on such problems as disarmament, chemical and biological warfare, science education and the drift from science. The new society has also set its eyes on local issues-air and river pollution and noise, for example--which could act as specific activities for local groups. The great appeal of the recent anti-Concorde campaign has obviously not gone unnoticed. As well as starting working groups, the society has also discussed the possibilities of a newsletter and of establishing panels of speakers to spread the gospel of scientific responsibility. After the April 19 meeting plans will no doubt harden. For one thing the society will have to appoint its officers. According to Dr D. H. Butt, a member of the ad hoc committee, Professor Maurice Wilkins is a likely candidate for the presidency, Dr Robert Smith of St Mary's Hospital Medical School will stay as secretary and the committee will probably remain unchanged. These are, however, seen as temporary arrangements and there is a plan for elections of officers in September. By then the society should have got off the ground and will include, as well as scientists, anyone interested in its ideals.

Money is, of course, a problem. The society seems to have rejected the suggestion that it should be affiliated with any political party and will rely on what funds it can raise independently. So far it has had two offers of $£ 100$ as well as free office facilities at 42 Great Russell Street, and various members have been paid by the BBC for interviews. It also intends to charge a membership fee of about $£ 1$ and to raise money from publications and lectures. And, as old hands know, a great deal can be achieved by voluntary labour. Professor E. H. S. Burhop, for example, of University College, London, who has campaigned for these issues since the thirties in a number of organizations, including the old Association of Scientific Workers and Pugwash, said last week that what had most impressed him was the large number of young people at the three meetings so far. He said he had not seen such enthusiasm among young academics and students since the thirties. But the best will in the world will be no substitute for cash when it comes to arranging meetings and real business. The Royal Society, for example, is not sponsoring the April 19 meeting but merely letting its lecture room, although for a new society the cachet of the Royal Society's name is worth the cost.

The other problem which the new society has yet to tackle is its relationship with other organizations, notably Pugwash. Several of the new society's members are also members of Pugwash, so it ought to be simple enough to organize informal contact. But should there be more formal links ? The international activities of Pugwash are quite different from those projected by the BSSRS. Pugwash is unashamedly an organization for the scientific élite of various nations, who often have the ear of their governments. The BSSRS says it is determined to play down personalities once it is established and to represent the rank and file as well as the élite of the scientific community. It will certainly lose much of its student support if it does otherwise. But what about the national Pugwash group, which cannot be accused of being overactive? The British Pugwash group seems certain to be the first organization to suffer when the BSSRS gets under way. But so far there have been no formal contacts between the BSSRS and the British Pugwash group, nor has the British group met to discuss the implications of the new society. 